\title{
ECOLOGICAL VALUE OF CEMETERY IN JAKARTA
}

\section{ABSTRACT}

Dian Priharyaningsih

School of Environmental Science, University of Indonesia

Hayati Sari Hasibuan

School of Environmental Science,

University of Indonesia

Email: sarihsb@gmail.com

\section{Raldi Koestoer}

School of Environmental Science,

University of Indonesia
Cemetery Parks currently have a highly demand by urban community. The fact that settlement competing with the park. The study of green open space of cemetery was relatively limited to be observed. The objective of the study is to determine the potential of Cemetery Parks in absorbing carbon. The research was conducted in Tanah Kusir and Kampung Kandang cemetery parks. The methodology applied to Quadran Typology. The balanced ecological assessment for both parks showed that the carbon absorption demonstrating significant results. And related trees as for Glodogan (Polyathea longifolia), Rambutan (Nephelium lappaceum) and Tanjung (Mimusops elengi), achieving gradual levels of carbon absorption.

Keywords: Carbon absorption, Cemetery Green, Open Space

\section{INTRODUCTION}

Urban conditions in Indonesia has a dynamic population growth. Population growth is influenced by birth, death and migration. An increase in the activity of socioeconomic activities and people's mobility, eventually demanding needs of urban space (Yunus, 2000). DKI Jakarta is one of the major cities that experienced an increase in the number of high populations. This causes the need for space, both for residential and other space feels very important, especially the need for green open space (GOS). GOS is a green area that was built to provide a very important benefit for the health and well-being throughout life, and contribute to the sustainability of the region. (Villanueva et al., 2015). Cemetery is one of the urban GOS that needs to be optimized function like other green space in cities

DKI Jakarta has $7.639,83 \mathrm{~km}^{2}$ area, population in Jakarta constantly increasing, although its growth decline. In 2014 the population growth by $1,11 \%$ with population density is 10.075 .300 million population of 15.212 inhabitants $/ \mathrm{km}^{2}$. In 2015 population growth of 1,09\% with population increasingly become 10.777 .900 million with population density of 15.367 inhabitants $/ \mathrm{km}^{2}$ (SCB, 2016). The birth rate in DKI Jakarta Province continued to increase in these 10 years. In 2014, the birth rate in DKI Jakarta Province reaches 2,3 per 1.000 people per year (WCEBFP, 2015). The high population density in an area will cause problems for space. The population of this large impact on space requirements in Jakarta is getting bigger, better place to live and especially the need for cemetery parks.

Data from the Department of Parks and Cemeteries of DKI Jakarta Province (2014), the most total GOS in Jakarta consists of a green belt, parks and cemetery is $27.26 \mathrm{~km}^{2}$. From the spacious GOS in DKI Jakarta Province, a total of $5,9 \mathrm{~km}^{2}$ is open space for cemetery with the numbers are 78 cemetery parks spread in Jakarta which still has a capacity of as much as 56.909 death bodies in 2014. With an estimated mortality rate of 100 bodies per day buried in cemetery parks in Jakarta, it is estimated the need of GOS for cemetery progressively increasing, especially in South Jakarta.

The needs of cemetery increasing as well as the target of the need for GOS in urban areas is makes cemetery park is very important to be re-examined its function. Other than as a burial land it can also be used as GOS with other functional as recreational place with comfort and safe so that it can be utilized optimally by the community to remain maintain harmony, alightment and sanctity. It underlies the researchers to examine and evaluate the implementation of the reforms and the development of cemetery in Jakarta, especially in South Jakarta so that the cemetery park can be GOS which have ecologically, socially and economically functional to improve the quality of the environment.

\section{METHODS}

\section{Research Site}

Location of the study conducted in South Jakarta by choosing Tanah Kusir Cemetery Park with the consideration of this place because it is the largest cemetery park in South Jakarta and Kampung Kandang Cemetery Park with the consideration of this place because it is a pilot project in South Jakarta.

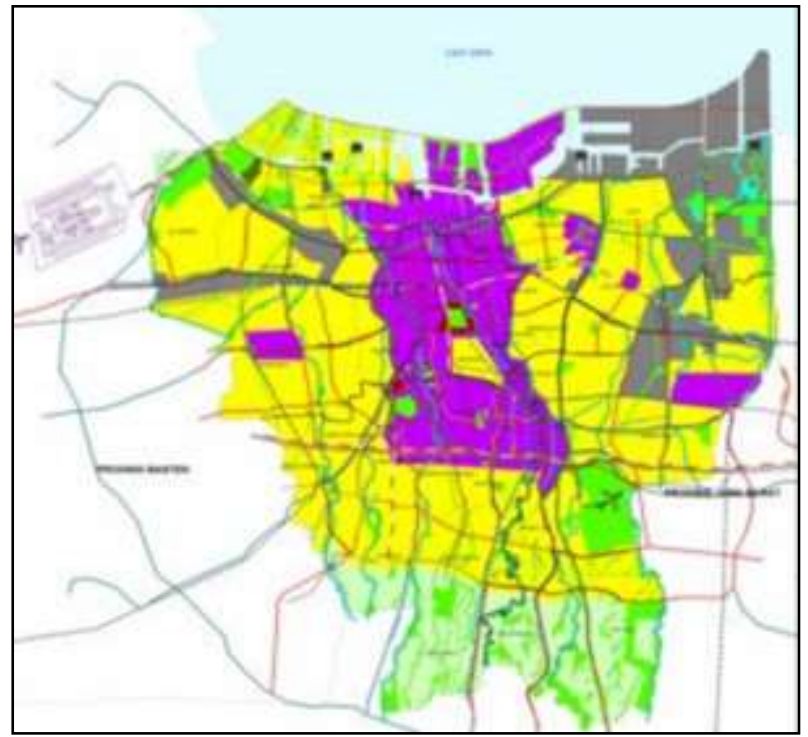

Figure 1. Study area of Cemetery Parks

Inventory and Sampling Methods of Tree

Tree inventory was conducted to determine the number and type of trees found in the location study. The sampling 
method for the analysis of tree vegetation is done using the quadrant method. Methods quadrant or quadrants center point method is a method of sampling without the sample plots. In the quadrant method, at each point of measurement is made abscissa and ordinate imaginary line, so that at each measurement point there are four quadrants. Then have one tree in each quadrant that is located closest to the measurement point and measure the distance of each measurement point to the tree and the tree diameter. The tree diameter is measured by Diameter at Breast Height (DBH) were calculated with 1,3 m height from the ground. Tree height is obtained based on the data in 2015 that has been held before.

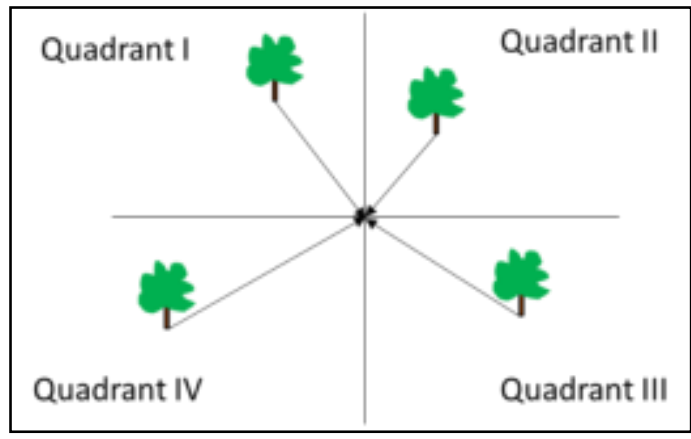

Figure 2. Inventory and Tree Sampling

\section{Data Analysis}

Determination of the amount of carbon stored by calculating the volume of trees and the potential for carbon sequestration using the following equations (Rahayu, 2015):

a) Volume of tree $(\mathrm{V})=\Pi \times 1 / 4 \times \mathrm{D}^{2} \times \mathrm{H} \times$ figures stem form

Information:

$\mathrm{V}$ : volume of tree $(\mathrm{m} 3)$

П: 3,14

D: Diameter $(\mathrm{m})$

$\mathrm{H}$ : High (m)

figures stem form: 0,7

b) The carbon content of stands tucked calculated using the formula from IPCC GPG (2006) and IPCC GL (2003):

Carbon $(\mathrm{C})=(\mathrm{V} \times \mathrm{D} \times \mathrm{BEF}) \times(1+\mathrm{R}) \times \mathrm{CF}$

Information:

C: Carbon content

$\mathrm{V}$ : Volume of tree

D: Density wood

BFF : Biomass expansion factor (the ratio between the above-ground biomass with branch-free trunk biomass, ie 3.4 IPCC default rate CPG (2013).

$\mathrm{R}$ : The ratio between the roots and the top of the tree $(0,27$ is default rate o IPCC CPG (2003).

CF : Carbon fraction from biomass $(0,5)$

\section{RESULT AND DISCUSSION}

\section{Result}

a) Tanah Kusir Cemetery Park

Tanah Kusir Cemetery Park is at a location $6^{\circ} 15^{\prime} 12$ "latitude and $106^{\circ} 46^{\prime} 11^{\prime \prime}$ E, located on Jl. Bintaro Raya No. 1, Kebayoran Lama, Jakarta Selatan. This place is the largest cemetery park in South Jakarta with an area 55,04 Ha. Tanah Kusir Cemetery Park is is one of the public cemeteries where many fighters and national figures were also buried there as Bung Hatta, Ali Sadikin, TB. Simatupang, etc.

Tanah Kusir Cemetery Park is is one of GOS which can be utilized as one of the locations of bird habitat in Jakarta for its strategic position (Fahlevi, 2013). Further this place is connecting of five major locations in Jakarta bird habitat. The locations are the riverbanks of Pesanggrahan River, Pondok Indah, Kebayoran Region, Region of Senayan, and Srengseng urban forest.

b) Kampung Kandang Cemetery Park

Kampung Kandang Cemetery Park is at a location $6^{\circ} 19^{\prime} 9$ "latitude $106^{\circ} 48^{\prime} 37^{\prime \prime}$ E, located on Jl. Raya Ciganjur, Jagakarsa, Jagakarsa, South Jakarta with an area 22.94 Ha. Kampung Kandang Cemetery Park is one of seed in South Jakarta area. Structuring of this place is very neat, orderly and clean. In this cemetery there are no tombs fighters or national hero buried in this place. Shady location and convenient cause this place is often used by people to exercise such as walking, running, relaxing and playing.

c) Tree Species and Important Value Index in Tanah Kusir Cemetery Park

Based on research in Tanah Kusir Cemetery Park in six plot point of the research, there were 24 trees with Important Value Index (IVI) ranged from 2,83\% - 109,54\%. The type of sample trees which have the high of IVI value are Glodogan, Tabebuia, and Pine tree. The three types of these trees each have value IVI of $109.54 \% ; 65.32 \%$ and $54.25 \%$. The highest IVI value can be interpreted that the third type of tree is a tree species that is most commonly found during the observation done. The lowest IVI based on the observation owned by Walisongo tree species that have a value IVI of $2.83 \%$. This tree species is based on field observations did not dominate the GOS of cemetery; the numbers were not commonly found in Tanah Kusir Cemetery Park.

d) Tree Species and Important Value Index in Kampung Kandang Cemetery Park

Based on observations in Kampung Kandang Cemetery Park in four plot point of the research found as many as five species of trees sampled. Number of trees samples is 16 individual samples, obtained IVI ranged between $16,81 \%-130,72 \%$. The type of sample trees which have the high of IVI value are Glodogan, Bintaro and Tanjung with the value of each IVI is $130,72 \% ; 89,38 \%$ and $32,75 \%$. The third type is based on the observation of the tree has dominated The Kampung Kandang Cemetery Park. Results of the smallest IVI owned by the Flamboyan tree with IVI of $16,81 \%$. Flamboyan tree based on observations of the very few growing in The Kampung Kandang Cemetery Park

e) Carbon Stored in Tanah Kusir Cemetery Park

Based on the results, trees that produce the most significant carbon huge in Tanah Kusir Cemetery Park is Glodogan that is equal to 53,92 tons of trees were observed by 4 sample trees, followed by Angsana tree with 24,92 tons to the amount observed in 1 sample trees.

f) Carbon Stored in Kampung Kandang Cemetery Park Based on the results, trees that produce the most significant carbon huge in Kampung Kandang Cemetery Park is glodogan that is equal to 34,37 tons of trees were observed by 7 sample trees, followed by a rambutan tree as much as 11,38 tons of trees were observed by 1 tree samples. 

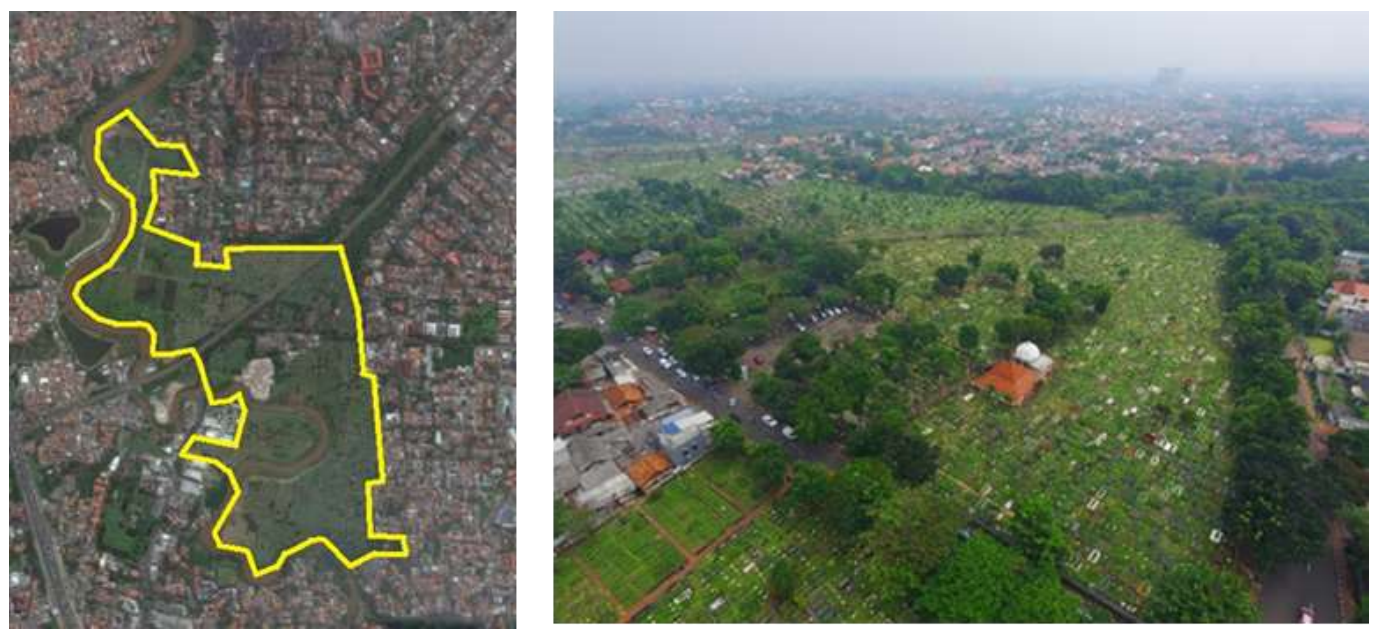

Figure 3. Tanah Kusir Cemetery Landscape
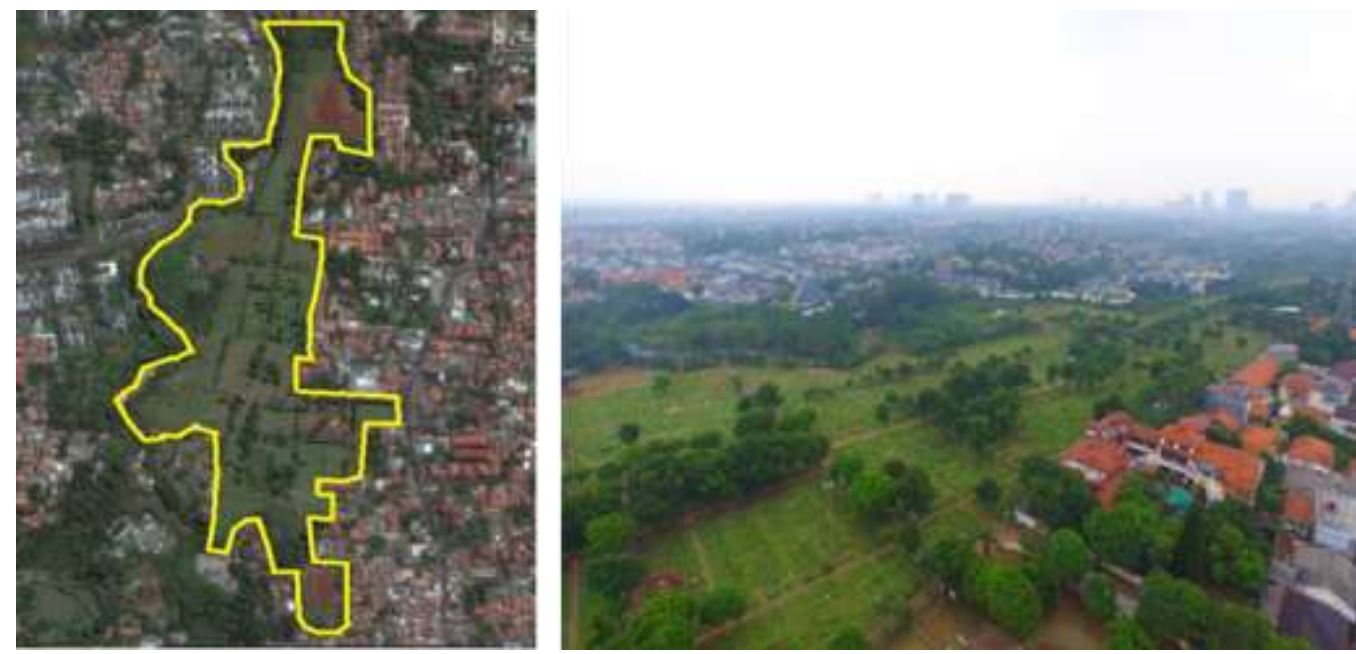

Figure 4. Kampung Kandang Cemetery Park Landscape

\section{Discussion}

Based on research in both locations of cemetery parks, the existing vegetation in the cemetery has the potential ability to absorb carbon per hectare was 4.26 tonnes of carbon per hectare or 0.63 tons of biomass/ha for trees that exist in the Tanah Kusir Cemetery Park. While the tree in Kampung Kandang Cemetery Park has the potential to absorb carbon per hectare was 4.36 tonnes of carbon per hectare, or 0.60 tons of biomass/ha. Trees that have high carbon absorption capacity at both locations are Glodogan while the Palm trees as well as a sample of trees found in this study has a carbon dioxide absorption values lower result. It is not appropriate to the research conducted by the (Putri et al., 2013) which states that Palm tree absorbs carbon dioxide has a higher ability than the glodogan as has the number, width and length of stomata higher than the glodogan. The difference this result is possible because of the carbon content of a species depends on the diameter and height dimensions as well as the density of the wood, the greater these dimensions then greater the potential carbon owned (Samsoedin and Wibowo, 2012).

By comparing Cemetery Park with other public GOS such as Monas Park, cemeteries have the ability to absorb carbon per hectare less than the other GOS, this is due to differences in the composition of vegetation cover in each type of GOS as expressed by Samsoedin and Wibowo (2012). However, cemetery parks remain to be an important consideration for the sustainability of the urban environment.

\section{CONCLUSION}

Ecological value of cemetery GOS base on the vegetation of tree planted, obtained the highest Important Value Index in Tanah Kusir and Kampung Kandang cemetery parks is owned by species of Glodogan with IVI of 109,54\% in Tanah Kusir Cemetery Park and 130,72\% in Kampung Kandang Cemetery Park. Ecological value of tree vegetation's ability to absorb carbon is obtained that the potential uptake of carbon per hectare in Tanah Kusir Cemetery Park with an area 55.04 ha is 4,26 ton of carbon per hectare or 0,63 ton of biomass/ha with the tree species that have the higher abilities to absorption of carbon are Glodogan, Angsana and Tabebuia. For the location of Kampung Kandang Cemetery Park with 22,94 ha potential carbon uptake per hectare was 4,36 ton of carbon per hectare, or 0,60 ton of biomass/ha with the tree species that have the higher carbon absorption abilities are Glodogan, Rambutan and Tanjung.

\section{REFERENCES}

Department of City Park and Cemetery DKI Jakarta Province. 2014. Garden Booklet of Jakarta. Jakarta, Indonesia: Government of DKI Jakarta Province.

Department of Parks and Cemeteries South Jakarta Administration City. 2015. Number of Trees in Park Cemetery. Jakarta, Indonesia: Government of DKI Jakarta Province. 
Fahlevi, S.R. 2013. Perancangan Ulang Kawasan Pemakaman Umum Tanah Kusir Jakarta sebagai Salah Satu Bentuk Pemanfaatan Ruang Terbuka Hijau Ramah Burung [Design Re-Zone Tanah Kusir Public Cemetery Jakarta as One form of Green Open Space Utilization Bird Friendly]. Bogor, Indonesia.

Putri, A.R., Lila, K.A, Astawa, I.N.G. 2013. Studi Tanaman Penghijauan Glodogan Tiang (Polythea longifolia), Kasia Emas (Cassia Surattensis), Kelapa (Cocos nucifera) sebagai Penyerap Emisi Gas Karbondioksida di Jalan PB. Sudirman Denpasar [Greening Plant Studies Glodogan Tiang (Polythea longifolia), Kasia Gold (Cassia Surattensis), Coconut (Cocos nucifera) As Absorbing Carbon Dioxide Emissions in PB. Sudirman Street, Denpasar] E-Jurnal Agroekoteknologi Tropika, 2 (2), 108-115.

Priharyaningsih. 2016. Pengembangan Ruang Terbuka Hijau Pemakaman di Perkotaan Studi di Jakarta Selatan [Development of Open Space in Urban Green Cemetery. Case Study: in South Jakarta)] Jakarta, Indonesia: Universitas Indonesia.

Rahayu, S. 2015. Optimalisasi Fungsi Peranan Taman Kota (Kajian di Taman Kota Menteng, Jakarta Pusat) [Optimizing the Role Function State Parks (Studies in Park City Menteng, Central Jakarta)]. Jakarta, Indonesia: Universitas of Indonesia.

Samsoedin, I., Wibowo, A. 2012. Analisis dan Kontribusi Pohon di Perkotaan dalam Menyerap Gas Rumah Kaca Studi kasus: Taman Kota Monumen Nasional, Jakarta [Potential Analysis and Contributions Trees in Urban Absorb Greenhouse Gases. Case study: Monumen Nasional Park Jakarta]. Social and Economic Research Journals Forestry, 9 (1), 42-53.

Statistical Central Bureau. 2016. South Jakarta in Figures 2016. Jakarta, Indonesia.

Villanueva, K., Badland, H., Hooper, P., Koohsari, J., Mavoa, S., Davern, M., Roberts, R., Goldfeld, S., Corti, B. 2015. Developing indicators of public open space to promote health and wellbeing in communities. Applied Geography. 57, 112-119.

Women and Community Empowerment Board to Family Planning. 2015. Performance Optimization Program Manager Family Planning to Achieve a prosperous new Jakarta. Jakarta, Indonesia.

Yunus, H. 2000. Urban Spatial Structure. Yogyakarta, Indonesia: Pustaka Pelajar. 